\title{
A construção do ator feminino em A mulher que escreveu a bíblia
}

Valci Aparecida Xavier GUIMARÃES

(Universidade de Franca)

RESUMO: Este estudo analisa o romance A mulher que escreveu a Bíblia, de Moacyr Scliar, por meio dos pressupostos teóricos da semiótica francesa. Observamos a construção do ator "mulher”, descrevendo os seus papéis actanciais e temáticos.

PALAVRAS-CHAVE: ator; papéis actanciais; papéis temáticos

ABSTRACT: This study analyses the novel The woman who wrote the Bible, by Moacyr Scliar, through theoretical presuppositions of the French semiotics. We observe the construction of the actor "woman", describing her actantial and thematic roles.

KEYWORDS: actor; actantial role; thematic role 
A mulher que escreveu a Bíblia conta a história de uma mulher que se submete a uma terapia de vidas passadas, o que a leva a descobrir, por meio da regressão, que foi ela quem escreveu a primeira versão do texto sagrado. O romance revela a trajetória desse sujeito feminino anônimo; filha de um pastor de cabras do deserto, ela é levada para Jerusalém, pois, pela tradição, o chefe de aldeia que mantivesse negócios com o rei, entregava-lhe a filha mais velha para que se tornasse uma de suas esposas. Assim, ela se concretiza no texto como uma das setecentas esposas do rei Salomão. Por ser a única letrada do harém, e demonstrar sua sabedoria e perspicácia, o soberano a encarrega de escrever a história do povo judeu.

O ator "mulher" cumpre vários papéis actanciais e temáticos ao longo da história. Sabe-se que tais papéis não são fixos, mas variam conforme o progresso narrativo, de acordo com Bertrand (2000:183). É importante lembrar que ela se projeta tanto no nível da enunciação, quanto no nível do enunciado. No excerto a seguir, observa-se a projeção do ator no presente da enunciação, por meio de desembreagem enunciativa. Nota-se que ela se dirige ao narratário, fazendo referência metadiscursiva à história que relata:

A feiúra é fundamental, ao menos para o entendimento desta história. É feia, esta que vos fala. Muito feia. Feia contida ou feia furiosa, feia vergonhosa ou feia assumida, feia modesta ou feia orgulhosa, feia triste ou feia alegre, feia frustrada ou feia satisfeita feia, sempre feia (Scliar, 2006:19) [grifos meus].

No nível do enunciado, o ator "mulher" é filha primogênita de um pastor de cabras do deserto e é dotada, no início da história, do papel temático de mulher submissa e subserviente, que acata as ordens do pai como chefe da aldeia e da família. É o que se observa em: "Uma primogênita era sempre um inconveniente, para dizer o mínimo: não garantia sucessão, não ajudava no trabalho e ainda precisaria de um dote para se casar" (Scliar, 2006:28). Ao ser levada pelo emissário real para ser uma das esposas do rei Salomão, pensa em resistir:

Se pudesse, me agarraria a ele em prantos e implorando, não deixes que me levem, por favor, quero ficar aqui contigo, com a mamãe, com minhas irmãzinhas. Mas eu não podia fazer isso. [...] afinal, era meu pai (Scliar, 2006:47).

Além disso, essa mulher carregava o estigma da feiúra. Ao perceber-se feia, quando se dá conta de sua imagem no espelho, é tomada por um turbilhão de estados de alma: da surpresa inicial, passa ao susto, ao inconformismo, à revolta e à raiva. Mesmo assim, ao chegar ao reino de Salomão e deparar-se com a beleza do rei, a mulher passa a tê-lo como objeto de desejo, mas é ignorada por ele, devido a sua feiúra. Só passa a aceitar essa sua condição, ao descobrir ser a "única letrada" no harém de 700 esposas e 300 concubinas. Desse modo, toma consciência de que pode usar a competência do saber letrado a seu favor. Isso se revela quando ela planeja a forma de conquistar o rei.

Assim, para a realização do programa narrativo de conquista do objeto-valor "rei Salomão", ela aguarda o momento adequado para organizar uma rebelião contra o regime opressivo sob o qual as mulheres viviam no harém de Salomão, estabelecendo uma aliança com elas. Tal aliança acontece logo depois que o rei passa duas semanas 
sem chamar nenhuma mulher para a cama, o que era raro acontecer, atitude que provocou uma inquietude no harém.

Nesse momento, ela organiza a rebelião, usando o seguinte estratagema de manipulação por provocação: espalha pelo harém o boato de que o rei dissera estar farto de suas mulheres, que seriam incompetentes, teriam limitadíssimo repertório sexual e, por isso, ele pensava em formar um outro harém. Logo, como castigo ao rei, por sugestão dela, as mulheres exigiram que ele recebesse primeiramente a feia em seus aposentos. Nesse momento de glória, em que ela comanda o movimento e é aplaudida, sente-se bela, beleza essa emanada do poder, como confirma o excerto:

E o que se via era uma mulher de pé sobre uma mureta, punho erguido no ar, cabelos em desalinho, rosto - belo rosto, sim, belo, muito belo, de uma beleza diferente, mas indiscutivelmente belo -, rosto resplandecente... (Scliar, 2006:91).

Para a conquista do objeto amado, ela tem, portanto, a competência da mulher consciente de seu poder. Entretanto, ao ser chamada por Salomão aos seus aposentos, o rei não consegue tê-la como esposa e ele culpa-a por isso:

- Agora: de quem é a culpa? É tua. Quem mandou ser tão feia? Além de feia, estúpida. Estou passando por um momento de grandes dificuldades, até ameaça de rebelião enfrento. O que se espera de uma esposa em circunstâncias assim? Compreensão, paciência. Mas não. Forçaste a barra, fizeste até um comício para me obrigar a te receber. Resultado: broxura. [...] Bem feito. É o castigo que mereces (Scliar, 2006:99).

Humilhada, ela redige uma carta ao pai, denunciando o rei por não cumprir suas obrigações de marido, entretanto, tal carta é apreendida por um guarda e entregue a Salomão. Este, ao descobrir a competência de mulher letrada que ela detinha, passa a criar uma outra imagem a seu respeito e the atribui o encargo de ser redatora do reino, escrevendo a história do povo judeu. Assim, sua feiúra é superada pela sabedoria e perspicácia.

O papel temático de mulher revolucionária, tendo em vista a época em que se situava, manifesta-se quando ela se refere, em sua versão da escritura, ao mito da criação e alude ao tema da sexualidade. Desse modo, mostra-se subversora em relação a valores reacionários:

Na minha cabeça, Deus seria apenas a energia geradora, não uma figura antropomórfica a reinar sobre a criação. Que Salomão e outros o imaginassem como homem, a mim não importava. Expressaria minha descrença, o meu protesto, abstendo-me de descrever a divindade. Que o imaginassem como um velho de barbas brancas e olhar severo, a mim não importava.

"No começo criou Deus o céu e a terra". Pronto: estava escrito. E, a frase escrita, invadiu-me súbita euforia. Comecei a rir (Scliar, 2006:125).

Ainda escrevendo sobre a criação do primeiro homem e da primeira mulher, ela decide “corrigir os equívocos bíblicos” e mobiliza, para isso, suas próprias fantasias. 
Criados o primeiro homem e a primeira mulher enamoram-se loucamente um do outro, e aí transformam o Éden num cenário de arrebatadora paixão [...]. O encontro dos dois era, portanto, uma espécie de Big-Bang do sexo [...] sob o olhar benévolo de Deus (Scliar, 2006:127).

Esse papel se reitera quando ela demonstra sua indignação sobre a criação da mulher, contestando o texto bíblico: "E por que tinha sido a mulher criada de maneira diferente? A história da costela me parecia tola, para dizer o mínimo, ou talvez até uma afronta, considerando a modéstia dessa peça anatômica” (Scliar, 2006:127).

Ao mostrar o texto sobre o mito da criação ao rei, Salomão diz a ela que o submeteria ao crivo de leitura dos anciãos para que eles opinassem sobre o seu teor. A mulher, então, responde: “-Escuta Salomão — eu disse, esforçando-me por manter a calma, se vais ouvir aqueles velhos a respeito do meu texto, estamos perdendo tempo. Aqueles caras nunca o aprovarão” (Scliar, 2006:128).

Assim, fazendo valer seu ponto de vista, o ator "mulher" vai conquistando seu objeto-valor, “o rei”, e, após possuí-lo, abandona-o, adquirindo, por sua vez, o objetovalor "liberdade".

Constatamos, por meio desse exercício de leitura do texto de Scliar, que a construção da imagem do ator feminino é resultado de sua posição de narrador letrado que se sobrepõe à imagem da mulher "submissa" que ela revelara inicialmente. É essa competência que a leva a superar o estigma da mulher "feia" e de mulher objeto, subserviente aos desígnios patriarcais, construindo-se liberal e contestadora.

\section{REFERÊNCIAS BIBLIOGRÁFICAS}

BARROS, Diana Luz Pessoa de. Teoria semiótica do texto. São Paulo: Ática, 1990.

BERTRAND, Denis. Caminhos da semiótica literária. São Paulo: EDUSC, 2003.

FIORIN, José Luiz. Elementos de análise do discurso. São Paulo: Contexto, 1990.

FONTANILLE, Jacques \& ZILBERBERG, Claude. Tensão e significação. São Paulo: Humanitas, 2001.

GREIMAS, Algirdas Julien e COURTES, Joseph. Dicionário de semiótica. São Paulo: Cultrix, s/d.

SCLIAR, Moacir. A mulher que escreveu a Bíblia. São Paulo: Companhia das Letras, 2006.

Como citar este artigo:

GUIMARÃES, Valci Aparecida Xavier. A construção do ator feminino em A mulher que escreveu a Bíblia. Estudos Semióticos. [online] Disponível na Internet via WWW.URL: http://www.fflch.usp.br/dl/semiotica/es. Editor Peter Dietrich. Número 4, São Paulo, 2008.

Acesso em "dia/mês/ano". 